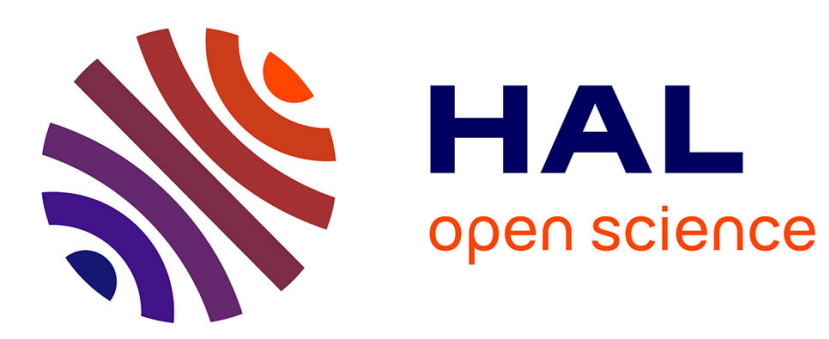

\title{
TiN-TixSiy Codeposits A.P.C.V.D. Produced Using the TiCl4-N2-SiH2Cl2-H2 System
}

\author{
G. Llauro, A. Bendeddouche, M. Nadal, R. Hillel
}

\section{To cite this version:}

G. Llauro, A. Bendeddouche, M. Nadal, R. Hillel. TiN-TixSiy Codeposits A.P.C.V.D. Produced Using the TiCl4-N2-SiH2Cl2-H2 System. Journal de Physique IV Proceedings, 1995, 05 (C5), pp.C5-801C5-807. 10.1051/jphyscol:1995595 . jpa-00253958

\section{HAL Id: jpa-00253958 https://hal.science/jpa-00253958}

Submitted on 1 Jan 1995

HAL is a multi-disciplinary open access archive for the deposit and dissemination of scientific research documents, whether they are published or not. The documents may come from teaching and research institutions in France or abroad, or from public or private research centers.
L'archive ouverte pluridisciplinaire HAL, est destinée au dépôt et à la diffusion de documents scientifiques de niveau recherche, publiés ou non, émanant des établissements d'enseignement et de recherche français ou étrangers, des laboratoires publics ou privés. 
JOURNAL DE PHYSIQUE IV

Colloque C5, supplément au Journal de Physique II, Volume 5, juin 1995

\title{
TiN-Ti $\mathrm{Si}_{y}$ Codeposits A.P.C.V.D. Produced Using the $\mathrm{TiCl}_{4}-\mathrm{N}_{2}-\mathrm{SiH}_{2} \mathrm{Cl}_{2}$ - $\mathrm{H}_{2}$ System
}

\author{
G. Llauro, A. Bendeddouche, M. Nadal and R. Hillel
}

IMP-CNRS, 66860 Perpignan cedex, France

\begin{abstract}
Mixtures of $\mathrm{TiN}_{\mathrm{X}}, \mathrm{TiSi}_{2}$ and $\mathrm{Ti}_{5} \mathrm{Si}_{3}(\mathrm{~N})$ were chemically vapour codeposited at atmospheric pressure using the $\mathrm{TiCl}_{4}-\mathrm{N}_{2}-\mathrm{SiH}_{2} \mathrm{Cl}_{2}-\mathrm{H}_{2}$ system. Compact materials with very intimately dispersed phases and with controlled

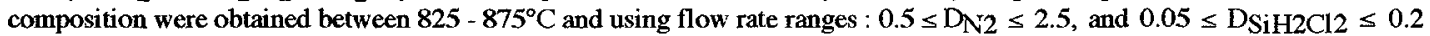
(in $1 / \mathrm{h}$ ). D $\mathrm{D}_{\mathrm{TiCl}} 4$ and $\mathrm{D}_{\mathrm{H} 2}$ were kept constant at 0.183 and 30 (in $\mathrm{l} / \mathrm{h}$ ) respectively. According to the Ti-Si-N ternary phase diagram, $\mathrm{TiN}_{\mathrm{x}}$ with $\mathrm{x}=0.95 \pm 0.05$, $\mathrm{TiSi}_{2}$ and $\mathrm{Ti}_{5} \mathrm{Si}_{3}(\mathrm{~N})$, corresponding to some solubility of nitrogen into $\mathrm{Ti}_{5} \mathrm{Si}_{3}$, were in thermodynamical equilibrium. At $850^{\circ} \mathrm{C}, \mathrm{D}_{\mathrm{TiCl}}=0.183$ and $\mathrm{D}_{2}=30$ (in $1 / \mathrm{h}$ ), the effect of $\mathrm{N}_{2}$ and $\mathrm{SiH}_{2} \mathrm{Cl}_{2}$ input concentrations were studied. At $\mathrm{D}_{\mathrm{SiH}} 2 \mathrm{Cl2}=0.1 \mathrm{l} / \mathrm{h}$, the deposition rate was found to increase linearly with the square root of the $\mathrm{N}_{2}$ molar fraction up to $5.10^{-2}$, then to decline at higher concentration. $\mathrm{TiN}_{\mathrm{X}}$ was $20 \mathrm{~mol} \%$ at $\mathrm{DN}_{\mathrm{N} 2}=0.51 / \mathrm{h}$, reached about $40 \mathrm{~mol} \%$ at $1 \mathrm{l} / \mathrm{h}$ and remained almost constant while $\mathrm{D}_{\mathrm{N} 2}$ increased to $2 \mathrm{l} / \mathrm{h}$. At $\mathrm{D}_{\mathrm{N} 2}=2 \mathrm{l} / \mathrm{h}$, about $70 \mathrm{~mol} \% \mathrm{in} \mathrm{TiN}$ was obtained with $\mathrm{DSiH}_{2 \mathrm{Cl} 2}=0.05 \mathrm{l} / \mathrm{h}$. Then from $\mathrm{DSiH}_{2 \mathrm{Cl}}$ ranging from 0,1 to $0.2 \mathrm{l} / \mathrm{h}$, TiN $\mathrm{N}_{\mathrm{X}}$ concentration remains almost equal to $35 \mathrm{~mol} \%$. A linear dependence in the $\mathrm{SiH}_{2} \mathrm{Cl}_{2}$ concentration was observed for the growth rate. The relationship between the logarithmic plot of the growth rate versus the reciprocal of codeposition temperature (in Kelvin) was linear and an apparent activation energy of $105 \mathrm{~kJ} / \mathrm{mol}$ was calculated. The effect of temperature on the TiN $\mathrm{N}_{\mathrm{X}}$ preferred orientations was also evidenced.
\end{abstract}

\section{INTRODUCTION}

The Ti-N-Si system is technologically interesting because of the properties of several of its compounds. TiN layers are particularly attractive because of their wear-resistance [1-2], erosion and abrasion-resistance [3-4], thermal stability, diffusion barrier applications [5-6], electroconductivity. But besides these positive properties, TiN coatings suffer from britteness, as well as the other ceramics, and all the more, from limited oxidation resistance [7-11]. An improvement of these behaviours could be to incorporate titanium silicides in TiN by chemical vapour codeposition. On one hand, the toughening effect of particule dispersion in a ceramic matrix is well established [12-14]. On the other hand, the oxidation resistance of titanium silicides is well known [15-16]. Two TiN-Ti $\mathrm{Si}_{\mathrm{y}}$ deposited materials were already described. A film for semiconductor manufacture produced by OMCVD at low pressure and temperature using $\mathrm{Ti}\left[\mathrm{N}\left(\mathrm{CH}_{3}\right)_{2}\right]_{4}$ and an organic silane source [17]. An hard and very thin coating prepared by reactive sputtering process from a $\mathrm{Ti}_{\mathbf{x}} \mathrm{Si}_{\mathbf{y}}$ target in a $\mathrm{Ar}-\mathrm{N}_{2}$ gas mixture[18]. More recently, an amorphous film corresponding to $\mathrm{Si}$ incorporation in $\mathrm{TiN}$ was chemical vapour deposited from tetrakis (diethylamino) $\mathrm{Ti}$ $\mathrm{NH}_{3}-\mathrm{SiH}_{4}$ mixture [19].

The objective of this present work was to prepare thick and compact $\mathrm{TiN}_{\mathrm{N}} \mathrm{Ti}_{\mathrm{x}} \mathrm{Si}_{\mathrm{y}}$ composites by chemical vapour deposition. The mixture was $\mathrm{TiCl}_{4}-\mathrm{N}_{2}-\mathrm{SiH}_{2} \mathrm{Cl}_{2}-\mathrm{H}_{2}$ and has never been used for this type of codeposition. This paper reports on the effect of the experimental parameters on the growth rate and phase composition of the codeposits.

\section{EXPERIMENTAL PROCEDURE}

Deposits were prepared by conventional thermal CVD, under atmospheric pressure. The reactor chamber consisted of a vertical silica tube $(\phi=6.2 \mathrm{~cm}, \mathrm{~L}=20 \mathrm{~cm})$. The codeposition was onto mechanically polished crystalline graphite substrate (Le Carbone-Lorraine $1116 \mathrm{~T}$; thickness $=1.2 \mathrm{~mm}$; thermal expansion coefficient $=6.10^{-6}{ }^{\circ} \mathrm{C}^{-1}$ ) resistivily heated. The substrate shape was designed to obtain a uniformly heated 
zone of $25 \times 5 \mathrm{~mm}^{2}$ (fig.1). The temperature was P.I.D regulated and measured with a thermocouple (TKI). Liquid $\mathrm{TiCl}_{4}$, gaseous $\mathrm{SiH}_{2} \mathrm{Cl}_{2}$ and $\mathrm{N}_{2}$ in hydrogen were used as reactant sources. The principle of the gas distribution system is given in figure 1 .

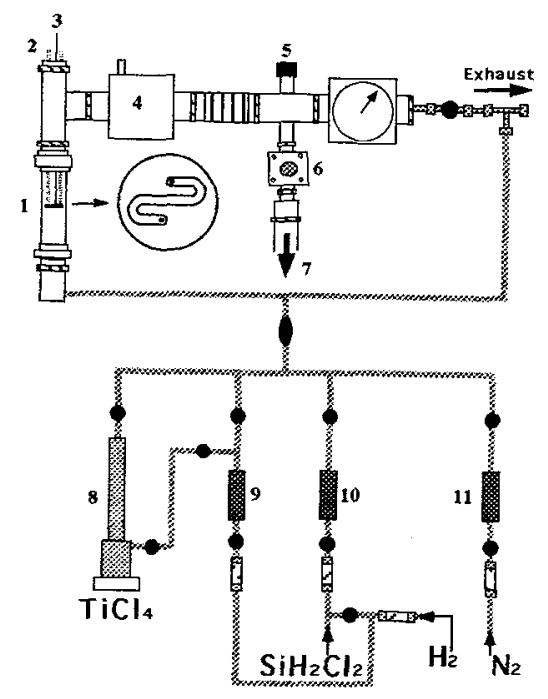

Figure 1: Experimental arrangement and shape of the graphite substrate ( 1: reactor, 2: Joule heating line, 3: thermocouple, 4: liquid nitrogen trap, 5: Pirani gauge, 6: pressure regulating valve, 7: vacuum pump, 8: dew - point column, 9-10-11: mass flow - meters ).

The $\mathrm{TiCl}_{4}$ flow rate was calculated from its partial pressure imposed by the regulated temperature of a column through which flowed the hydrogen stream saturated with $\mathrm{TiCl}_{4}$ after to be bubbled through heated liquid $\mathrm{TiCl}_{4}$. Samples of different compositions were prepared by varying both the deposition temperature and the flow rates of the input gas species $\left(\mathrm{DN}_{2}, \mathrm{DSiH}_{2} \mathrm{Cl} 2, \mathrm{DTiCl}_{4}\right.$ and $\left.\mathrm{D}_{\mathrm{H}}\right)$. The process time was chosen of 1 or 2 hours in order to obtain a thickness deposit of at least $40 \mu \mathrm{m}$.

The surface morphology of the polished cross sections and surface deposits was observed using an optical microscope and a scanning electron microscope. After having verified that the growth rates were almost independent of time, deposition rate was expressed in thickness per hour. The elemental compositions were obtained from photoelectron spectroscopy measurements carried out using a Riber SIA-200 spectrometer equipped with a monochromatic $\mathrm{Al} \mathrm{K} \alpha \mathrm{X}$-ray radiations source: $1486.6 \mathrm{eV}$. Calibration was based upon the Cls photoelectron peak of adventitious carbon at $284.6 \mathrm{eV}$. The relative intensities of the Ti2p, Si $2 \mathrm{p}$ and N1s peaks were used for the quantitative evaluations The nature of the crystalline phases was determined by X-ray diffraction (Philips PW 1710, Cu Ka: 1.5418 Å).

\section{RESULTS AND DISCUSSION}

\subsection{Multiphased codeposits}

Samples of different compositions were prepared by varying both the codeposition temperature and concentrations of the input gas species. Temperature was varied between 800 to $1000^{\circ} \mathrm{C}$ and the variation ranges of the different flow rates were: $0.5 \leq \mathrm{DN}_{2} \leq 2.5$, and $0.05 \leq \mathrm{DSiH}_{2} \mathrm{Cl} 2 \leq 0.2$. D TiCl4 and $\mathrm{DH}_{2}$ were kept constant at 0.183 and 30 (in $1 /$ h) respectively. All deposits were crystalline and have a colour ranged from yellow gold to light grey. Whatever the experimental conditions at least two phases were identified from their X-ray diffraction lines: the non - stoichiometric compound $\mathrm{TiN}_{\mathbf{X}}$ and $\mathrm{Ti}_{5} \mathrm{Si}_{3}(\mathrm{~N})$ corresponding to some solubility of nitrogen into $\mathrm{Ti}_{5} \mathrm{Si}_{3}$ [20-22]. In addition, depending mainly on the temperature of codeposition, $\mathrm{TiSi}_{2}$ was detected in some samples. The X-ray diffraction lines corresponding to $\mathrm{TiN}_{\mathrm{X}}: 111,200,220,311,222$ and 420 , were assigned by comparison with those listed in the JCPDS file no.6-0642 (cubic system - Fm3m). The X-ray reflections of TiSi 2 (orthorhombic system - Fddd; JCPDS file no.35-785) were identified in the samples prepared above $850^{\circ} \mathrm{C}$. Whatever the 
codeposition temperature $\left(825-950^{\circ} \mathrm{C}\right)$, the X-ray diffraction pattern of $\mathrm{Ti}_{5} \mathrm{Si}_{3}(\mathrm{~N})$, corrected using $\mathrm{TiSi}_{2}$ as an internal reference, was unambiguously attributed by comparison with that of $\mathrm{Ti}_{5} \mathrm{Si}_{3}$ (hexagonal system P63/mcm; JCPDS file no. 29-1362). Because of dissolution of some amount of nitrogen, there were slight shifts of the X-ray reflections and modifications of the intensity lines (table I). These modifications, however, could also arise from the presence of a preferred orientation of the crystals. As a matter of fact, the strongest diffraction line was (002) for codeposits obtained in the range $825-900^{\circ} \mathrm{C}$ (table 1) instead of (012) above $900^{\circ} \mathrm{C}$.

Table I: X-ray diffraction lines of $\mathrm{Ti}_{5} \mathrm{Si} 3(\mathrm{~N})$ corresponding to a codeposit prepared at: $850^{\circ} \mathrm{C}, \mathrm{D}_{\mathrm{N} 2}=1.5, \mathrm{D}_{\mathrm{SiH} 2 \mathrm{Cl} 2}=0.1$, $\mathrm{D}_{\mathrm{TiCl} 4}=0.183$ and $\mathrm{D}_{\mathrm{H} 2}=30(\mathrm{in} \mathrm{l} / \mathrm{h})$.

\begin{tabular}{|c|c|c|}
\hline $\mathrm{d}(\AA)$ & $\mathrm{I} / \mathrm{lo}$ & $\mathrm{hkl}$ \\
\hline 2.587 & 100 & 002 \\
\hline 2.402 & 35 & 012 \\
\hline 2.210 & 3 & 121 \\
\hline 1.409 & 6 & 123 \\
\hline 1.294 & 46 & 004 \\
\hline 1.222 & 2 & 240 \\
\hline
\end{tabular}

From several spectra, average lattice parameters values of an hexagonal cell were calculated : $a=0.7424 \pm$ $0.0008 \mathrm{~nm}$ and $c=0.517 \pm 0.004 \mathrm{~nm}$. In the same way, an average value, $a=0.4238 \pm 0.0003 \mathrm{~nm}$ of the lattice parameter of $\mathrm{TiN}_{\mathrm{X}}$ was evaluated. From the experimentally established relationships between the lattice parameter and the nitrogen-titanium ratio [23-24], $x$ was found of about 0.95. \pm 0.05 .

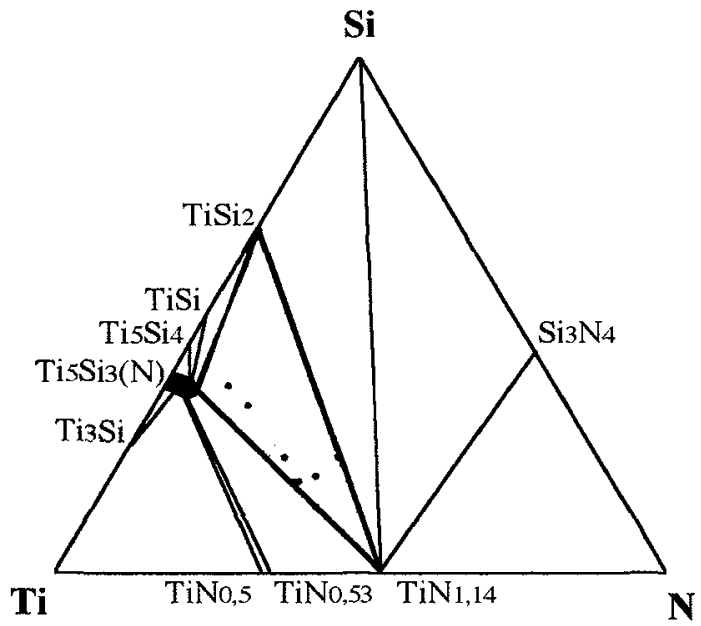

Figure 2: $\mathrm{Ti}-\mathrm{Si}-\mathrm{N}$ isothermal section and the plotted elementar compositions of codeposits prepared at atmospheric

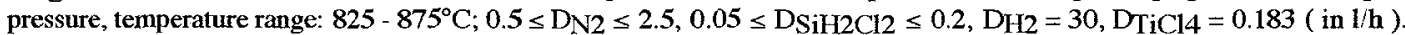

These results are consistent with the fact that according to the Ti-Si-N ternary phase diagram, $\mathrm{TiN}_{\mathbf{X}}, \mathrm{TiSi}_{2}$ and $\mathrm{Ti}_{5} \mathrm{Si}_{3}(\mathrm{~N})$ are in equilibrium. In the isothermal section represented in figure 2 , the compatibility relationships between $\mathrm{TiN}$ and $\mathrm{Si}, \mathrm{Si}_{3} \mathrm{~N}_{4}$ and $\mathrm{TiSi}_{2}$ originally selected by Beyers et al. [25] were complicated by the inclusion of recent data experimental established [21-22]. The stoichiometric range of $\mathrm{TiN}_{\mathrm{x}}$ is $0.53<\mathrm{x}<1.14, \mathrm{Ti}_{2} \mathrm{~N}$ and four titanium silicides: $\mathrm{Ti}_{3} \mathrm{Si}, \mathrm{Ti}_{5} \mathrm{Si}_{3}, \mathrm{Ti}_{5} \mathrm{Si}_{4}, \mathrm{TiSi}$ and $\mathrm{TiSi}_{2}$ were taken into account. A solid solution $\mathrm{Ti}_{5} \mathrm{Si}_{3}(\mathrm{~N})$ was assumed to equilibrate with $\mathrm{Ti}_{5} \mathrm{Si}_{4}, \mathrm{TiSi}$ and $\mathrm{TiSi}_{2}$. In the three-phase equilibrium among $\mathrm{Ti}_{5} \mathrm{Si}_{3}(\mathrm{~N})-\mathrm{TiSi}_{2}-\mathrm{TiN}_{\mathrm{x}}, \mathrm{x}$ is close to 1 , in agreement with our results. The fact that the lattice parameters of $\mathrm{Ti}_{5} \mathrm{Si}_{3}(\mathrm{~N})$ were slightly larger than those of $\mathrm{Ti}_{5} \mathrm{Si}_{3}$ coexisting with $\mathrm{Ti}_{5} \mathrm{Si}_{4}$ i.e $\mathrm{a}=0.7422 \mathrm{~nm}$ and $\mathrm{c}=0,51293 \mathrm{~nm}[20]$ was consistent with the nitrogen solubility.

The phase compositions of codeposits prepared between $825-875^{\circ} \mathrm{C}$ were evaluated by plotting the elementar compositions determined by XPS in the isothermal section (figure 2).Taking into account that $\mathrm{Ti}_{5} \mathrm{Si}_{3}$ dissolves about 10 at. $\%$ at $1100^{\circ} \mathrm{C},[22]$ we assumed a solubility of 5 at $\%$. 


\subsection{Effect of the experimental factors:}

Codeposits were prepared at atmospheric pressure and the influence of temperature and gas flow rates was studied in order to achieve dense materials with very intimately dispersed phases and of coarse with controlled composition.

From preliminary experiments performed at the initial conditions: $\mathrm{DN}_{2}=2, \mathrm{DSiH}_{2} \mathrm{Cl} 2=0.1, \mathrm{DTiCl}_{4}=$ 0.183 and $\mathrm{DH}_{2}=30$ (in $1 / \mathrm{h}$ ), we concluded that this main objective could be reached if the temperature was lower than $875^{\circ} \mathrm{C}$. Below $825^{\circ} \mathrm{C}$, the substrate was still incompletely covered after one hour of codeposition. Hence, the temperature was varied between $825^{\circ} \mathrm{C}$ to $875^{\circ} \mathrm{C}$. From additional experiments done at $850^{\circ} \mathrm{C}$ taking twice less or more as $0.183 \mathrm{l} / \mathrm{h}$ of $\mathrm{DTiCl}_{4}$, it appeared that the quality of the coatings was poor. Therefore, this initial $\mathrm{TiCl}_{4}$ flow rate was chosen for all the experiments.

\subsubsection{Effect of the $\mathrm{N}_{2}$ input concentration}

Keeping constant all the other initial factors, the effect of $\mathrm{DN}_{2}$ was studied at $850^{\circ} \mathrm{C}$ in the range $0.5-2 \mathrm{l} / \mathrm{h}$. The deposition rate was found to increase linearly with the square root of the $\mathrm{N}_{2}$ molar fraction up to $\mathrm{XN}_{2}$ $=5.10^{-2}$, then to decline at higher concentration (figure 3). The same dependence was already observed in the case of the deposition of TiN [26-28].

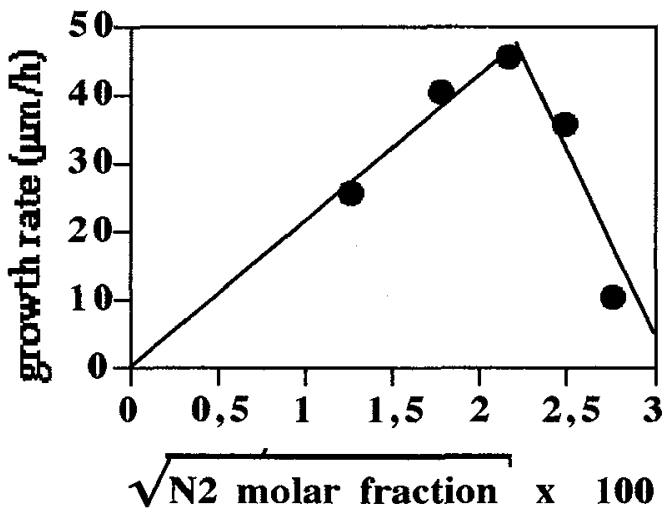

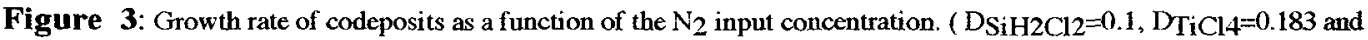
$\mathrm{DH}_{2}=30($ in $1 / \mathrm{h}), \mathrm{t}^{\circ} \mathrm{C}=850^{\circ} \mathrm{C}$ )

The TiN concentration in the codeposits was $20 \mathrm{~mol} \%$ at $0.51 / \mathrm{h}$, reached about $40 \mathrm{~mol} \%$ at $\mathrm{DN}_{2}=1 \mathrm{l} / \mathrm{h}$ and remained almost constant while $\mathrm{DN}_{\mathrm{N} 2}$ increased to $2 \mathrm{l} / \mathrm{h}$.

\subsubsection{Effect of the $\mathrm{SiH}_{2} \mathrm{Cl}_{2}$ input concentration}

To prepare TiN-rich composite, it was necessary to decrease the initial concentration in $\mathrm{SiH}_{2} \mathrm{Cl}_{2}$. At $850^{\circ} \mathrm{C}$ and $\mathrm{DN}_{2}=2, \mathrm{DH}_{2}=30(\mathrm{l} / \mathrm{h})$, a codeposit of about $70 \mathrm{~mol} \%$ in $\mathrm{TiN}$ was obtained with $\mathrm{DSiH}_{2} \mathrm{Cl} 2=0.05 \mathrm{l} / \mathrm{h}$ . Then from $\mathrm{DSiH}_{2 \mathrm{Cl}}$ ranging from 0.1 to $0.2 \mathrm{l} /$ the $\mathrm{TiN}$ concentration remains almost equal to $35 \mathrm{~mol} \%$ (figure 4).

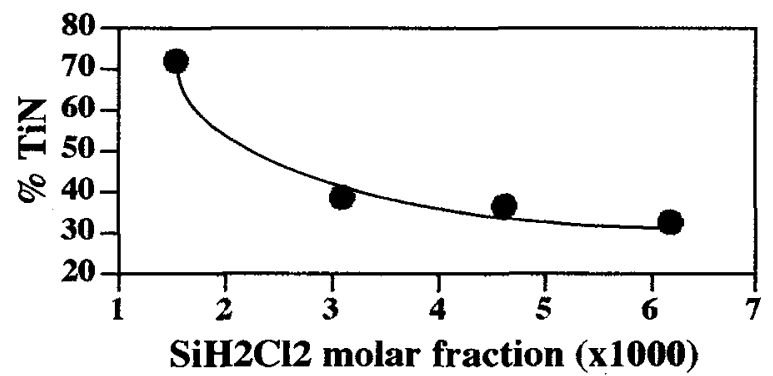

Figure 4: TiN concentration of the codeposits as a function of the $\mathrm{SiH}_{2} \mathrm{Cl}_{2}$ input concentration. $\left(\mathrm{DN}_{2}=2, \mathrm{D}_{\mathrm{TiCl}} 4=\right.$ 0.183 and $\mathrm{D}_{\mathrm{H} 2}=30($ in $1 / \mathrm{h}), 850^{\circ} \mathrm{C}$ ) 
For the growth rate a linear dependence in the $\mathrm{SiH}_{2} \mathrm{Cl}_{2}$ concentration seems to be observed (figure 5) while the N2 molar fraction remains almost equal to $6.10^{-2}$. The increasing of the thickness per hour is flat up to $3.10^{-3}$ then high over $4.10^{-4}$. In the first range, the deposition seems to be controlled by the $\mathrm{N}_{2}$ input concentration. The coating thickness remains constant at about 30-35 $\mu \mathrm{m}$ and also the TiN concentration at about 32-38 mol\%. Whereas in the second range, the deposition seems to be controlled by the $\mathrm{SiH}_{2} \mathrm{Cl}_{2}$ input concentration. The thickness increases significantly and also the quantities of the codeposited titanium silicides.

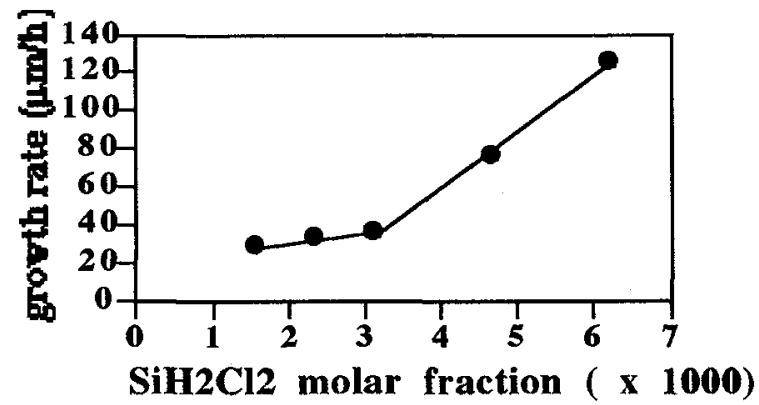

Figure 5: Growth rate of the codeposits as a function of the $\mathrm{SiH}_{2} \mathrm{Cl}_{2}$ input concentration. $\left(\mathrm{DN}_{\mathrm{N} 2}=2, \mathrm{D}_{\mathrm{TiCl}}=0.183\right.$ and DH2 $=30$ (in $1 / \mathrm{h}), 850^{\circ} \mathrm{C}$ )

\subsubsection{Effect of the temperature of codeposition}

The effect of the temperature in the range $825-950^{\circ} \mathrm{C}$ was studied at: $\mathrm{DN}_{2}=2, \mathrm{DSiH}_{2} \mathrm{Cl} 2=0.1, \mathrm{DTiCl}_{4}=$ 0.183 and $\mathrm{DH}_{2}=30$ (in $1 / \mathrm{h}$ ). Above $875^{\circ} \mathrm{C}$ the quality of the codeposits was very poor but it was possible to follow the evolution of the titanium silicides from X-ray analysis. The ratio of the intensities of the strongest lines (311) for $\mathrm{TiSi}_{2}$ and $(012)$ or $(002)$ for $\mathrm{Ti}_{5} \mathrm{Si}_{3}(\mathrm{~N})$ was evaluated. Figure 6 shows that the quantity of $\mathrm{TiSi}_{2}$ increases with temperature at the expense of $\mathrm{Ti}_{5} \mathrm{Si}_{3}(\mathrm{~N})$.

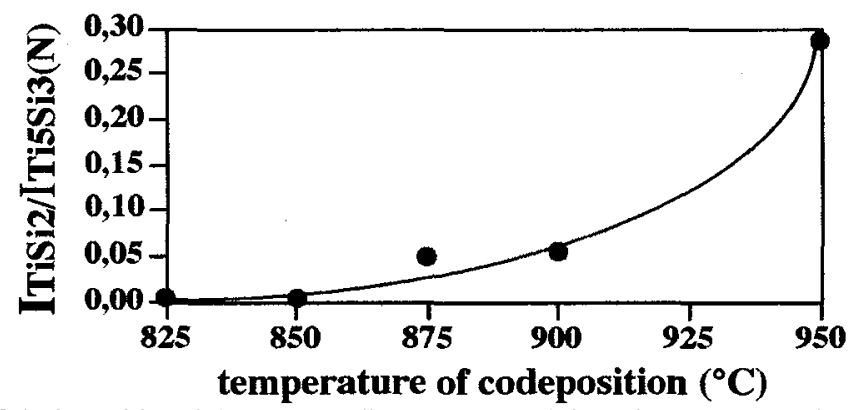

Figure 6: The ratio of the intensities of the strongest lines (311) for $\mathrm{TiSi}_{2}$ and $(012)$ or $(002)$ for $\mathrm{Ti}_{5} \mathrm{Si}_{3}(\mathrm{~N})$ in function of the temperature of codeposition.

The relationship between the logarithmic plot of the growth rate versus the reciprocal of codeposition temperature (in Kelvin) was linear (figure 7). From the slope of the fitted least square line, an apparent activation energy of $105 \mathrm{~kJ} / \mathrm{mol}$ was calculated which is high enough to suggest that the process is controlled by surface kinetics. This value is in the range $84-101 \mathrm{~kJ} / \mathrm{mol}$ of the experimental apparent activation energies corresponding to the chemical vapour deposition of $\mathrm{TiN}$ from $\mathrm{TiCl}_{4}-\mathrm{N}_{2}-\mathrm{H}_{2}$ [29-30]. 


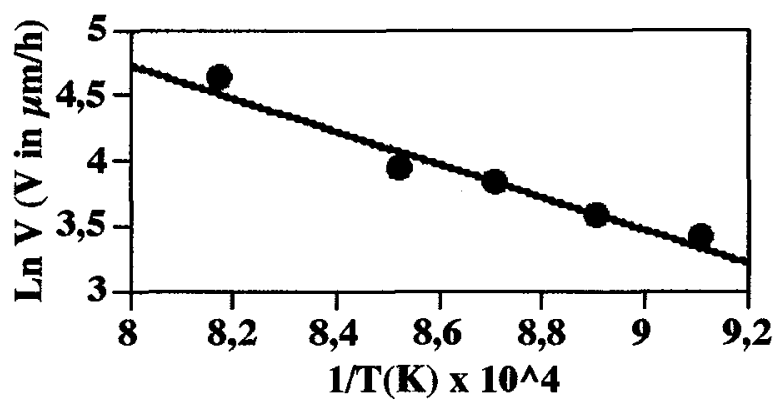

Figure 7: Logarithmic plot of the growth rate versus the reciprocal of codeposition temperature (in Kelvin). ( DN2 = 2 , $\mathrm{DSiH}_{2 \mathrm{Cl} 2}=0.1, \mathrm{DTiCl}_{4}=0.183$ and $\mathrm{DH}_{2}=30(\mathrm{in} 1 / \mathrm{h})$; temperature in the range $\left.825-950^{\circ} \mathrm{C}\right)$

The crystallographic orientations determined by XRD showed that (111), (200), (220), (311) and (420) orientations of $\mathrm{TiN}_{\mathrm{X}}$ were predominantly encountered in all codeposits. Taking into account these five main reflections, texture coefficients, tc (hkl) were calculated following the method of Harris [31]: $\operatorname{tc}(h k l)=\left[I_{\exp }(h k l) / I_{r}(h k l)\right] / 1 / n \sum\left[I_{\exp }(h k l) / I_{r}(h k l)\right]$ with the number of reflections $n=5 . I_{\exp }(h k l)$ is the measured intensity of the reflection (hkl) and $I_{r}(h k l)$ the intensity of the same reflection of the JCPDS powdered TiN (file no.6-0642) randomly deposited. A preferred orientation (311) was evidenced up to $900^{\circ} \mathrm{C}$ (figure 8). It decreased as the temperature of codeposition increased and at $950^{\circ} \mathrm{C} \mathrm{TiNx}$ was almost randomly deposited.

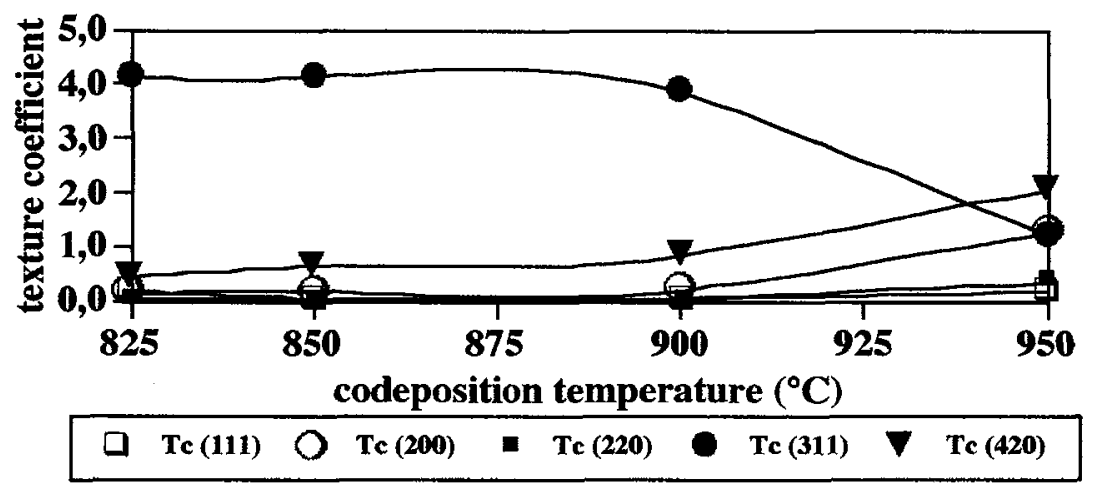

Figure 8: Texture coefficients of $\mathrm{TiN}_{X}$ in function of the codepostion temperature.

\section{CONCLUSION}

Thick and compact coatings consisting in a dispersion of titanium silicides in TiN were prepared by CVD using the $\mathrm{TiCl}_{4}-\mathrm{N}_{2}-\mathrm{H}_{2}-\mathrm{SiH}_{2} \mathrm{Cl}_{2}$ system at atmospheric pressure, between $825-875^{\circ} \mathrm{C}$ and with flow rates: $0.5 \leq \mathrm{DN}_{2} \leq 2.5,0.05 \leq \mathrm{DSiH}_{2} \mathrm{Cl}_{2} \leq 0.2, \mathrm{DH}_{2}=30$ and $\mathrm{DTiCl}_{4}=0.183$ (in $1 / \mathrm{h}$ ). Despite some lacks concerning the dependence on the $\mathrm{TiCl}_{4}$ and $\mathrm{H}_{2}$ input concentrations of phase ratio and growth rate, codeposit composition was controlled by varying $\mathrm{DN}_{2}$ and $\mathrm{DSiH}_{2} \mathrm{Cl} 2$. According to the Ti-Si-N ternary phase diagram, $\mathrm{TiN}_{\mathrm{x}}$ with $\mathrm{x}=0.95 \pm 0.05, \mathrm{TiSi}_{2}$ and $\mathrm{Ti}_{5} \mathrm{Si}_{3}(\mathrm{~N})$ were in thermodynamical equilibrium at the temperature of codeposition. The microstructures of these materials is examinating by TEM and HREM. The thermal stability of the codeposits at higher temperature will be studied and also the oxidation resistance. In addition, the effect of the $\mathrm{Ti}_{\mathbf{x}} \mathrm{Si}_{\mathbf{y}}$ inclusion on the mechanical behaviour of $\mathrm{TiN}_{\mathrm{x}}$ will be examined.

\section{References}

[1] Rebenne H.E. and Bhat D.G., Surf.Coat.Technol., 63 (1) (1994) 1-13.

[2] Chatterjee S., Chandrashekhar S. and Sudarshan T.S., J.Mater.Sci., 27 (1992) 3409-3423.

[3] D'alessio G. and Nagy D., J.Can.Ceram.Soc., 63 (1) (1994) 59-63. 
[4]Chatterjee S., Sudarshan T.S. and Chandrashekhar S., J.Mater.Sci., 27 (1992) 1989-2006.

[5] Weiser P.S., Prawer S., Hoffman A., Paterson P.J.K. and Manory R.R., J.Appl.Phys., 76 (4) (1994) 2164-2168.

[6] Gagnon G., Currie J.F., Béique G., Brebner J.L., Gujrathi S.C., Ouellet L. J.Appl.Phys., 75 (3) (1994) $1565-1570$

[7] Munz W.D., J.Vac.Sci.Technol.,A, 4 (6) (1986) 2717-2725.

[8] Jehn H.A., Hofman S. and Munz W.D., Thin Solid Films, 153 (1987) 45-53.

[9] Wittmer M., Noser J. and Melchior H., J.Appl.Phys., 52 (11) (1981) 6659-6664.

[10]Taniguchi S., Shibata T. and Okada A., SANS NOM, 4 (1989) 301-306.

[11] Suni I., Sigurd D., Ho K.T., Nicolet M-A., J;Electochem.Soc., 130 (1983) 1210-1214

[12] Becher P.F., J.Am.Ceram.Soc., 74 (2) (1991) 255-269.

[13] Rice R.W., Ceram.Eng.Sci.Proc., 2 (7-8) (1981) 661-701.

[14] Evans A.G., J.Am.Ceram.Soc., 72 (2) (1990) 187-206.

[15] Nicolet M.A. and Lau S.S., VLSI Electronics, microstructure Science (Academic Press, New York, 1983)' pp. 383-389

[16] Murarka S.P., J.Vac.Sci.Technol., 17 (4) (1980) 775-792.

[17] Sandhu G.S. et al., U.S. patent $n^{\circ} 5,252,518,12 / 10 / 93$.

[18] Yamagata $H$. et al. European patent $n^{\circ} 588,350,16 / 09 / 92$.

[19] Raaijmkers I.J., Thin Sold Film, 247 (1994) 85-93

[20] Phase Diagrams of Ternary Boron Nitride and Silicon Nitride Systems.(Edited by Rogl P., Schuster J.C., ASM International ,1993) pp.198-202

[21] Sambasivan S. and Petuskey W.T., J.Mater.Res., 9 (9) (1994) 2362-2369.

[22] Wakelkamp W., thèse, Eindhoven University, 1991.

[23]Jiang C.C., Goto T. and Hirai T., J.Alloys Compd., 190 (2) (1993) 197-200.

[24] Nagakura S., Kusunoki T., Kamimoto F., Hitsu Y., J.Appl.Crystallogr., 8(1975) 65-68

[25] Beyers R., Sinclair R. and Thomas M.E., J.Vac.Sci.Technol.,B, 2 (4) (1984) 781-784.

[26] Jung T.C., Sheng D.Y. and Fang M.H., Proc. of the X Intern. Conf. on CVD, Honolulu USA, Cullen G.W., Blocher J.M. (Eds), (1987) 81-90

[27] Bhat D.G., Proc. of the XI Intern. Conf. on CVD, Seattle USA, Cullen G.W., Spear K.E. (Eds), (1990) 648-655

[28] Shah D.C., Bhat D.G., Surface modification technologies IV ( The minerals, metals and materials Society, 1991) pp.70-95

[29] Jiang C.C., Goto T. and Hirai T., J.Mater.Sci., 28 (1993) 6446-6449.

[30] Dekker J.P., Van der Put P.J., Veringa H.J. and Schoonman J., J.Electfochem.Soc., 141 (3) (1994) 787-795.

[31] Barrett C., Massalski T.B. Structure of metals,( Pergamon Press, Oxford, third edition 1980) pp. 204-205. 